\title{
Pengembangan Sistem Pakar Diagnosa Gangguan Autisme Menggunakan Metode Naive Bayes
}

\author{
Ni Made Putri Kesumawardani ${ }^{1}$, Gede Aditra Pradnyana ${ }^{2}$, I Made Agus Wirawan ${ }^{3}$ \\ Program Studi Pendidikan Teknik Informatika \\ Jurusan Teknik Informatika \\ Fakultas Teknik dan Kejuruan \\ Universitas Pendidikan Ganesha \\ Email : madeputri36@gmail.com ${ }^{1}$, gede.aditra@undiksha.ac.id ${ }^{2}$,imade.aguswirawan@undiksha.ac.id ${ }^{3}$
}

\begin{abstract}
Abstrak - Semua orang tua mengharapkan memiliki anak yang sehat, membanggakan, dan sempurna, akan tetapi, terkadang kenyataan yang terjadi tidak sesuai dengan keinginan. Sebagian orang tua mendapatkan anak yang diinginkannya dan sebagian lagi tidak. Beberapa di antaranya memiliki anak dengan kebutuhan-kebutuhan khusus, seperti mengalami Autisme. Di Indonesia sendiri setiap tahunnya anak autisme terus mengalami peningkatan tahun 2015 diperkirakan terdapat kurang lebih 12.800 anak dengan autisme dan 134.000 anak dengan spektrum Autisme di Indonesia sayangnya lagi pengetahuan dan kesadaran masyarakat dan orang tua mengenai hal ini masih sangat minim. Selain minim informasi dan pengetahuan, anggapan-anggapan yang sudah melekat juga membuat orang tua enggan menyerahkan anaknya untuk mendapat perawatan. Oleh karena itu, peneliti mencoba membantu permasalahan yang dihadapi tersebut dengan mengembangkan sebuah sistem pakar diagnosa Autisme menggunakan metode Naive Bayes. Dimana metode tersebut digunakan untuk melakukan pengklasifikasian diagnosa berdasarkan inputan yang diberikan pengguna. Dalam evaluasi yang telah dilakukan metode ini memiliki skor akurasi $100 \%$ dari 15 data yang diujikan, skor kesesuaian $100 \%$ dan uji respon pengguna sebesar 75,7 dari 100 .
\end{abstract}

Kata Kunci : Sistem Pakar, Autisme, Naive Bayes, SUS

Abstract-All parents expect to have children who are healthy, proud, and perfect, however sometimes the facts that occur are not as desired. Some parents get the child they want and some don't. Some of them have children with special needs, such as experiencing Autism. In Indonesia, every year autistic children have been increase in 2015 and it is estimated that there are approximately 12,800 children with autism and 134,000 children with a spectrum of Autism in Indonesia, unfortunately the knowledge and awareness of the public and parents about this is still really less. In addition to lack information and knowledge, the assumptions that have been attached also make parents reluctant to give up their children for treatment. Therefore, researchers tried to help the problems faced by developing a expert system for Autism diagnoses using the Naive Bayes method. Where the method is used to classify diagnoses based on input given by the user. In evaluations that have been made this method has a $100 \%$ accuracy score of 15 data tested, 100\% conformity score and user response test of 75.7 out of 100.

Keywords: Expert System, Autisme, Naive Bayes, SUS

\section{PENDAHULUAN}

Anak merupakan sebuah karunia yang besar bagi orang tuanya. Keberadaannya diharapkan dan di tunggu-tunggu serta disambut dengan penuh bahagia. Semua orang tua mengharapkan memiliki anak yang sehat, membanggakan, dan sempurna, akan tetapi, terkadang kenyataan yang terjadi tidak sesuai dengan keinginan. Sebagian orang tua mendapatkan anak yang diinginkannya dan sebagian lagi tidak. Beberapa di antaranya memiliki anak dengan kebutuhan-kebutuhan khusus, seperti mengalami Autisme [1]

Pemakaian istilah Autisme pertama kali diperkenalkan oleh Leo Kanner seorang psikiater pada tahun 1943. Di mana pada saat itu Leo Kanner mengadakan pengamatan terhadap 11 anak yang menunjukkan gejala kesulitan berhubungan dengan orang lain, mengisolasi diri, perilaku yang tidak biasa, dan cara berkomunikasi yang aneh [2]. Autisme berasal dari kata "autos" yang berarti segala sesuatu yang mengarah pada diri sendiri

Di Indonesia sendiri setiap tahunnya anak autisme terus mengalami peningkatan. Menteri Kesehatan Siti Fadilah Supari dalam pembukaan rangkaian Expo Peduli Autisme 2008 lalu mengatakan, jumlah anak autisme di Indonesia tahun 2004 tercatat sebanyak 475.000 anak Tahun 2015 diperkirakan terdapat kurang lebih 12.800 anak dengan autisme dan 134.000 anak dengan spektrum Autisme di Indonesia[3].

Berdasarkan wawancara awal yang dilakukan peneliti dengan Paul Gervais selaku pakar mengatakan bahwa deteksi anak dengan gangguan autisme dapat dilakukan sejak anak berusia 1,5 tahun, akan tetapi disarankan untuk hasil yang lebih 
baik deteksi autisme dilakukan pada anak usia sekolah atau sekitar 4-5 tahun.

Seiring dengan bertambahnya jumlah anak autisme yang ada dan masih minimnya sumber daya yang bisa menjadi psikolog dan therapist serta banyak dokter yang belum begitu mengerti mengenai autisme di daerah-daerah atau pusat kesehatan yang menyulitkan orang tua untuk melakukan penanganan dini. Hal ini menyebabkan seringnya terjadi salah diagnosa seperti, anak dianggap kurang stimulasi, mengalami gangguan bicara, ADHD atau keterbelakangan mental[4].

Berdasarkan pemaparan di atas maka penulis berinisiatif untuk membuat suatu aplikasi yang dapat membantu orang tua dalam melakukan pendeteksian dini pada anak dengan gangguan autisme. Serta dapat membantu orang tua untuk memahami apa itu autisme dan cara penanganannya.

\section{KAJIAN TEORI}

\section{A. Autisme}

Istilah autisme sendiri telah ada sejak tahun 1943 dikemukakan pertama kali oleh Psikiater Leo Kanner, dari Austria. Autisme berasal dari kata autos (bahasa Yunani) yang berarti self atau 'diri-sendiri'. Jadi penyandang Autisme pada dasarnya merupakan seseorang yang cenderung menikmati kegiatan dengan dirinya sendiri. Autisme pada hakikatnya adalah gangguan perkembangan neuro-biologi yang luas pada anak. Gangguan ini menimbulkan masalah bagi si kecil, dalam hal berkomunikasi dan menjalin hubungan dengan lingkungan. Akibatnya, anak autisme tak dapat berinteraksi dengan siapa pun secara berarti, karena ketidakmampuannya memahami apa yang dimaksud orang lain[5].

Secara umum, anak autisme memiliki gangguan dalam hal komunikasi, interaksi sosial, imajinasi, pola perilaku berulang dan tak mudah menyesuaikan diri terhadap perubahan. Gangguan interaksi sosial ini menyebabkan mereka jadi tampak 'aneh' dan berbeda dengan anak lainnya. Gangguan komunikasi terjadi baik pada komunikasi verbal (dengan katakata) maupun nonverbal (gerak tubuh, ekspresi wajah, dan nada suara).

Berdasarkan berita yang diterbitkan WebMD pada 24 Mei 2012 dengan judul Most Children With Autism Diagnosed at 5 or Older (Mann, 2012) yang di tulis oleh Denise Mann. Mengatakan lebih dari setengah anak-anak usia sekolah di diagnosis dengan gangguan spektrum Autisme dan penelitian menunjukkan kurang 20\% anak di diagnosis pada usia 2 tahun, karena beberapa anak yang mengalami gangguan Autis Ringan mungkin tidak dapat diidentifikasi sampai anak memasuki usia sekolah. [6]

B. DSM 5 (Diagnostic and Statistical Manual of Mental Disorder)

Diagnostic and Statistical Manual of Mental Disorders (DSM) adalah klasifikasi gangguan mental dengan kriteria yang dirancang oleh APA untuk memfasilitasi diagnosis gangguan mental yang lebih handal. Profesional dalam bidang kesehatan mental, seperti Dokter Anak, Psikiater, dan Psikologi biasa menggunakan DSM dalam menyusun diagnosa Autisme. DSM5 yang mulai disahkan penggunaannya pada bulan Mei 2013 menyatakan tidak ada satu cara atau tes untuk menentukan Autisme. Diagnosis perlu mempertimbangkan hasil pembicaraan dengan orang tua, untuk mengetahui riwayat anak, dan mengobservasi bagaimana perilaku dan gejala anak. Adapun beberapa kriteria yang di paparkan dalam DSM-5 antara lain:

a) Kurangnya komunikasi dan interaksi sosial yang bersifat menetap pada berbagai konteks.

b) Perilaku yang terbatas, pola perilaku yang repetitif, ketertarikan, atau aktivitas yang termanifestasi minimal dua dari perilaku berikut:

c) Gejala-gejala harus muncul pada periode perkembangan awal (tapi mungkin tidak termanifestasi secara penuh sampai tuntutan sosial melebihi kapasitas yang terbatas, atau mungkin tertutup dengan strategi belajar dalam kehidupannya).

d) Gejala-gejala menyebabkan perusakan yang signifikan pada kehidupan sosial, pekerjaan atau setting penting dalam kehidupan.

e) Gangguan-gangguan ini lebih baik tidak dijelaskan dengan istilah ketidakmampuan intelektual (intellectual disability), gangguan perkembangan intelektual atau keterlambatan perkembangan secara global[7].

\section{Naive Bayes}

Naïve Bayes merupakan sebuah pengklasifikasian probabilistik sederhana yang menghitung sekumpulan probabilitas dengan sejumlah frekuensi dan kombinasi nilai dari dataset yang diberikan. Definisi lain mengatakan Nä̈ve Bayes merupakan pengklasifikasian dengan metode probabilitas dan statistik yang dikemukakan oleh ilmuan Inggris Thomas Bayes, yaitu dengan cara memprediksi peluang masa depan berdasarkan pengalaman di masa sebelumnya. Naïve Bayes didasarkan pada asumsi penyederhanaan bahwa nilai atribut secara kondisional saling bebas jika diberikan nilai output. Adapun persamaan yang digunakan pada metode ini adalah sebagai berikut:

$$
\mathrm{P}(\mathrm{H} \mid \mathrm{X})=\frac{P(X \mid H) \cdot P(H)}{P(X)}
$$

$\begin{array}{ll}\text { Dimana: } & \\ \mathrm{X} & \text { : Data dengan class yang belum diketahui } \\ \mathrm{H} & \text { : Hipotesis data merupakan suatu class } \\ & \text { spesifik } \\ \mathrm{P}(\mathrm{H} \mid \mathrm{X}) & \text { : Probabilitas hipotesis H berdasar kondisi } \\ & \text { X(posteoriti probabilitas) } \\ \mathrm{P}(\mathrm{H}) & \text { :Probabilitas hipotesis H (prior probabilitas) }\end{array}$


ISSN 2252-9063

Kumpulan Artikel Mahasiswa Pendidikan Teknik Informatika

(KARMAPATI)

KARMAPATI

$\begin{array}{ll}\mathrm{PxX} \mid \mathrm{H}) & \begin{array}{l}\text { : Probabilitas X berdasarkan kondisi pada } \\ \text { hipotesis H }\end{array} \\ \mathrm{P}(\mathrm{X}) & : \text { Probabilitas X }[8]\end{array}$

1. Skema Naive Bayes

Adapun alur dari metode Naive Bayes adalah sebagai berikut:

a. Mulai

b. Baca Training

1. Hitung $\mathrm{P}(\mathrm{Ci})$ untuk setiap kelas

2. Hitung $\mathrm{P}(\mathrm{X} \mid \mathrm{Ci})$ untuk setiap kriteria dan setiap kelas

3. Cari $\mathrm{P}(\mathrm{X} \mid \mathrm{Ci})$ yang paling besar menjadi kesimpulan

c. Tampilkan hasil Prediksi

Data gangguan autisme yang digunakan pada penelitian ini berjumlah 39 gangguan gejala, yang mana meliputi gangguan pada interaksi, komunkasi, imajinasi dan koherensi. Akan tetapi pada perhitungan berikut digunakan hanya 10 data dari data gejala sebagai contoh perhitungan, berikut adalah data yang digunakan pada pehitungan naive bayes.

Tabel 1 Data Kode Gejala

\begin{tabular}{|c|l|}
\hline Kode & \multicolumn{1}{|c|}{ Gejala } \\
\hline G1 & Kontak mata \\
\hline G2 & Senyum sosial \\
\hline G3 & Mengungkapkan rasa sakit \\
\hline G4 & Kondisi yang berubah \\
\hline G5-dst. & Kontak mata dan ekspresi \\
\hline
\end{tabular}

Tabel 2 Data Kode Jawaban

\begin{tabular}{|c|c|}
\hline Kode & Jawaban \\
\hline T & Tidak \\
\hline J & Jarang \\
\hline KK & Kadang-kadang \\
\hline B & Baik \\
\hline SB & Sangat Baik \\
\hline
\end{tabular}

Tabel 3 Data Kode Diagnosa

\begin{tabular}{|c|l|}
\hline Kode & \multicolumn{1}{c|}{ Diagnosa } \\
\hline ASD & $\begin{array}{l}\text { Anak terindikasi memiliki gangguan } \\
\text { autisme. }\end{array}$ \\
\hline Bukan ASD & $\begin{array}{l}\text { Anak tidak terindikasi memiliki gangguan } \\
\text { Autisme }\end{array}$ \\
\hline
\end{tabular}

Tabel 4 Dataset Gejala

\begin{tabular}{|l|c|c|c|c|c|c|c|c|c|c|}
\hline \multirow{2}{*}{$\begin{array}{l}\text { Gejal } \\
\text { a }\end{array}$} & 1 & 2 & 3 & 4 & 5 & 6 & 7 & 8 & 9 & 10 \\
\hline G1 & $\mathrm{T}$ & $\mathrm{K}$ & $\mathrm{J}$ & $\mathrm{J}$ & $\mathrm{K}$ & $\mathrm{J}$ & $\mathrm{J}$ & $\mathrm{B}$ & $\mathrm{SB}$ & $\mathrm{K}$ \\
& & $\mathrm{K}$ & & & $\mathrm{K}$ & & & & & $\mathrm{K}$ \\
\hline
\end{tabular}

Volume 8, Nomor 2, Tahun 2019

\begin{tabular}{|c|c|c|c|c|c|c|c|c|c|c|}
\hline \multirow{2}{*}{$\begin{array}{l}\text { Gejal } \\
\text { a }\end{array}$} & \multicolumn{10}{|c|}{ Data Ke- } \\
\hline & 1 & 2 & 3 & 4 & 5 & 6 & 7 & 8 & 9 & 10 \\
\hline G2 & $\mathrm{J}$ & $\begin{array}{l}\mathrm{K} \\
\mathrm{K}\end{array}$ & $\mathrm{J}$ & $\mathrm{T}$ & $\mathrm{B}$ & $\mathrm{J}$ & $\begin{array}{l}\mathrm{K} \\
\mathrm{K}\end{array}$ & $\begin{array}{l}\mathrm{K} \\
\mathrm{K}\end{array}$ & B & SB \\
\hline G3 & $\mathrm{T}$ & $\begin{array}{l}\mathrm{K} \\
\mathrm{K}\end{array}$ & $\mathrm{J}$ & $\mathbf{J}$ & B & $\mathrm{J}$ & B & SB & B & $\begin{array}{l}\mathrm{K} \\
\mathrm{K}\end{array}$ \\
\hline G4 & $\mathrm{J}$ & $\mathrm{T}$ & $\mathrm{J}$ & $\mathrm{T}$ & $\mathbf{J}$ & $\mathrm{T}$ & $\mathrm{J}$ & $\begin{array}{l}\mathrm{K} \\
\mathrm{K}\end{array}$ & B & B \\
\hline G5 & $\mathrm{T}$ & $\mathrm{J}$ & $\mathrm{J}$ & $\mathrm{T}$ & $\begin{array}{l}\mathrm{K} \\
\mathrm{K}\end{array}$ & $\mathrm{J}$ & $\mathrm{J}$ & SB & B & B \\
\hline G6 & $\mathrm{T}$ & $\mathrm{J}$ & $\mathrm{T}$ & $\mathrm{J}$ & B & $\mathrm{J}$ & $\begin{array}{l}\mathrm{K} \\
\mathrm{K} \\
\end{array}$ & SB & B & SB \\
\hline G7 & $\mathrm{T}$ & $\mathrm{T}$ & $\mathrm{T}$ & $\bar{T}$ & $\begin{array}{l}\mathrm{K} \\
\mathrm{K}\end{array}$ & $\mathrm{J}$ & $\mathrm{J}$ & $\begin{array}{l}\mathrm{K} \\
\mathrm{K}\end{array}$ & B & SB \\
\hline G 8 & $\mathrm{~T}$ & $J$ & $\mathrm{~T}$ & $T$ & $\begin{array}{l}\mathrm{K} \\
\mathrm{K}\end{array}$ & $\mathrm{J}$ & $\mathrm{J}$ & $\begin{array}{l}\mathrm{K} \\
\mathrm{K}\end{array}$ & B & B \\
\hline G9 & $\mathrm{T}$ & $\mathrm{J}$ & $\mathrm{T}$ & $\mathrm{J}$ & $\mathrm{B}$ & $\begin{array}{l}\mathrm{K} \\
\mathrm{K}\end{array}$ & $\mathrm{J}$ & $\begin{array}{l}\mathrm{K} \\
\mathrm{K}\end{array}$ & B & $\begin{array}{l}\mathrm{K} \\
\mathrm{K}\end{array}$ \\
\hline G10 & $\mathrm{T}$ & $\mathrm{J}$ & $\mathrm{J}$ & $\mathrm{J}$ & $\begin{array}{l}\mathrm{K} \\
\mathrm{K}\end{array}$ & $\begin{array}{l}\mathrm{K} \\
\mathrm{K}\end{array}$ & $\mathrm{J}$ & $\begin{array}{l}\mathrm{K} \\
\mathrm{K}\end{array}$ & SB & SB \\
\hline G11 & $\mathrm{T}$ & $\begin{array}{l}\mathrm{K} \\
\mathrm{K}\end{array}$ & $\mathrm{J}$ & $\mathrm{T}$ & $\begin{array}{l}\mathrm{K} \\
\mathrm{K}\end{array}$ & $\mathrm{J}$ & $\begin{array}{l}\mathrm{K} \\
\mathrm{K}\end{array}$ & $\begin{array}{l}\mathrm{K} \\
\mathrm{K}\end{array}$ & B & $\begin{array}{l}\mathrm{K} \\
\mathrm{K}\end{array}$ \\
\hline G12 & $\mathrm{T}$ & $\mathrm{T}$ & $\mathrm{T}$ & $\mathrm{J}$ & $\mathrm{J}$ & $\mathrm{J}$ & $\mathrm{J}$ & $\mathrm{J}$ & $\mathrm{J}$ & $\begin{array}{l}\mathrm{K} \\
\mathrm{K}\end{array}$ \\
\hline G13 & $\mathrm{T}$ & $\mathrm{J}$ & $\mathrm{T}$ & $\mathrm{T}$ & $\begin{array}{l}\mathrm{K} \\
\mathrm{K}\end{array}$ & $\mathrm{J}$ & $\mathrm{J}$ & $\mathrm{B}$ & B & B \\
\hline G14 & $\mathrm{J}$ & $\begin{array}{l}\mathrm{K} \\
\mathrm{K}\end{array}$ & $\mathrm{J}$ & $\mathrm{J}$ & $\mathrm{B}$ & $\mathrm{J}$ & $\begin{array}{l}\mathrm{K} \\
\mathrm{K}\end{array}$ & SB & SB & B \\
\hline G15 & $\mathrm{T}$ & $\mathrm{J}$ & $\mathrm{J}$ & $\mathrm{J}$ & $\mathrm{B}$ & $\mathrm{T}$ & $\begin{array}{l}\mathrm{K} \\
\mathrm{K}\end{array}$ & SB & SB & B \\
\hline G16 & $\mathrm{T}$ & $\mathrm{T}$ & $\mathrm{T}$ & $\mathrm{T}$ & $\begin{array}{l}\mathrm{K} \\
\mathrm{K}\end{array}$ & $\mathrm{T}$ & B & B & $\begin{array}{l}\mathrm{K} \\
\mathrm{K}\end{array}$ & B \\
\hline G17 & $\mathrm{T}$ & $\mathrm{J}$ & $\begin{array}{l}\mathrm{K} \\
\mathrm{K}\end{array}$ & $\mathrm{J}$ & $\mathrm{B}$ & $\mathrm{J}$ & $\mathrm{J}$ & B & B & B \\
\hline G18 & $\mathrm{T}$ & $\mathrm{J}$ & $\mathrm{J}$ & $\mathrm{J}$ & $\begin{array}{l}\mathrm{K} \\
\mathrm{K}\end{array}$ & $\mathrm{J}$ & $\mathrm{J}$ & $\mathrm{B}$ & B & B \\
\hline G19 & $\mathrm{T}$ & $\mathrm{J}$ & $\mathrm{J}$ & $\mathrm{J}$ & $\mathrm{B}$ & $\mathrm{J}$ & $\mathrm{J}$ & B & B & $\begin{array}{l}\mathrm{K} \\
\mathrm{K}\end{array}$ \\
\hline G20 & $\mathrm{T}$ & $\mathrm{J}$ & $\mathrm{T}$ & $\mathrm{T}$ & $\begin{array}{l}\mathrm{K} \\
\mathrm{K}\end{array}$ & $\mathrm{T}$ & $\mathrm{J}$ & $\begin{array}{l}\mathrm{K} \\
\mathrm{K}\end{array}$ & $\begin{array}{l}\mathrm{K} \\
\mathrm{K}\end{array}$ & B \\
\hline G21 & $\mathrm{J}$ & $\begin{array}{l}\mathrm{K} \\
\mathrm{K}\end{array}$ & $\begin{array}{l}\mathrm{K} \\
\mathrm{K}\end{array}$ & $\mathrm{J}$ & $\mathrm{B}$ & $\mathrm{J}$ & $\begin{array}{l}\mathrm{K} \\
\mathrm{K}\end{array}$ & B & SB & SB \\
\hline G22 & $\mathrm{T}$ & $T$ & $\mathrm{~T}$ & $T$ & $\mathrm{~J}$ & $\mathrm{~T}$ & $\mathrm{~T}$ & SB & SB & $\mathrm{B}$ \\
\hline G23 & $\mathrm{T}$ & $\mathrm{J}$ & $\begin{array}{l}\mathrm{K} \\
\mathrm{K}\end{array}$ & $\mathrm{J}$ & $\begin{array}{l}\mathrm{K} \\
\mathrm{K}\end{array}$ & $\mathrm{J}$ & $\mathrm{J}$ & SB & B & B \\
\hline G24 & $\mathrm{T}$ & $\mathrm{J}$ & $\begin{array}{l}\mathrm{K} \\
\mathrm{K}\end{array}$ & $\mathrm{J}$ & $\begin{array}{l}\mathrm{K} \\
\mathrm{K}\end{array}$ & $\mathrm{J}$ & $\mathrm{J}$ & $\begin{array}{l}\mathrm{K} \\
\mathrm{K}\end{array}$ & B & $\begin{array}{l}\mathrm{K} \\
\mathrm{K}\end{array}$ \\
\hline G25 & $\mathrm{T}$ & $\mathrm{T}$ & $\mathrm{T}$ & $\mathrm{T}$ & $\mathrm{J}$ & $\mathrm{T}$ & $\mathrm{T}$ & SB & B & SB \\
\hline G26 & $\mathrm{J}$ & $\mathrm{T}$ & $\mathrm{T}$ & $\mathrm{T}$ & $\begin{array}{l}\mathrm{K} \\
\mathrm{K}\end{array}$ & $\mathrm{T}$ & $\mathrm{T}$ & SB & SB & B \\
\hline G27 & $\mathrm{T}$ & $\mathrm{T}$ & $\mathrm{T}$ & $\mathrm{T}$ & $\begin{array}{l}\mathrm{K} \\
\mathrm{K}\end{array}$ & $\mathrm{J}$ & $\begin{array}{l}\mathrm{K} \\
\mathrm{K}\end{array}$ & $\begin{array}{l}\mathrm{K} \\
\mathrm{K}\end{array}$ & $\begin{array}{l}\mathrm{K} \\
\mathrm{K}\end{array}$ & B \\
\hline
\end{tabular}


ISSN 2252-9063

Kumpulan Artikel Mahasiswa Pendidikan Teknik Informatika

(KARMAPATI)

KดRMดPดTI

\begin{tabular}{|c|c|c|c|c|c|c|c|c|c|c|}
\hline \multirow{2}{*}{$\begin{array}{l}\text { Gejal } \\
\text { a }\end{array}$} & \multicolumn{10}{|c|}{ Data Ke- } \\
\hline & 1 & 2 & 3 & 4 & 5 & 6 & 7 & 8 & 9 & 10 \\
\hline G28 & $\mathrm{T}$ & $\mathrm{T}$ & $\mathrm{T}$ & $\mathrm{T}$ & $\mathrm{J}$ & $\mathrm{T}$ & $\mathbf{J}$ & $\begin{array}{l}\mathrm{K} \\
\mathrm{K}\end{array}$ & $\begin{array}{l}\mathrm{K} \\
\mathrm{K}\end{array}$ & $\begin{array}{l}\mathrm{K} \\
\mathrm{K}\end{array}$ \\
\hline G29 & $\mathrm{T}$ & $\begin{array}{l}\mathrm{K} \\
\mathrm{K}\end{array}$ & $\mathrm{T}$ & $\mathrm{T}$ & $\begin{array}{l}\mathrm{K} \\
\mathrm{K}\end{array}$ & $\mathbf{J}$ & $\begin{array}{l}\mathrm{K} \\
\mathrm{K}\end{array}$ & $\begin{array}{l}\mathrm{K} \\
\mathrm{K}\end{array}$ & $\begin{array}{l}\mathrm{K} \\
\mathrm{K}\end{array}$ & $\mathrm{J}$ \\
\hline G30 & $\mathrm{T}$ & $\mathbf{J}$ & $\mathrm{J}$ & $\mathbf{J}$ & B & $\mathrm{T}$ & $\mathbf{J}$ & $\begin{array}{l}\mathrm{K} \\
\mathrm{K}\end{array}$ & $\mathrm{B}$ & B \\
\hline G31 & $\mathrm{T}$ & $\mathbf{J}$ & $\mathbf{J}$ & $\mathbf{J}$ & B & $\mathrm{T}$ & $\begin{array}{l}\mathrm{K} \\
\mathrm{K}\end{array}$ & $\mathrm{B}$ & SB & B \\
\hline G32 & $\begin{array}{l}\mathrm{K} \\
\mathrm{K}\end{array}$ & $\mathbf{J}$ & $\begin{array}{l}\mathrm{K} \\
\mathrm{K}\end{array}$ & $\begin{array}{l}\mathrm{K} \\
\mathrm{K}\end{array}$ & B & $\mathrm{J}$ & $\begin{array}{l}\mathrm{K} \\
\mathrm{K}\end{array}$ & B & SB & SB \\
\hline G33 & $\mathrm{T}$ & $\mathrm{T}$ & $\mathrm{T}$ & $\mathrm{T}$ & $\begin{array}{l}\mathrm{K} \\
\mathrm{K}\end{array}$ & $\mathrm{T}$ & $\mathbf{J}$ & $\begin{array}{l}\mathrm{K} \\
\mathrm{K}\end{array}$ & $\mathrm{J}$ & $\begin{array}{l}\mathrm{K} \\
\mathrm{K}\end{array}$ \\
\hline G34 & $\mathrm{T}$ & $\mathrm{T}$ & $\mathbf{J}$ & $\mathrm{T}$ & $\begin{array}{l}\mathrm{K} \\
\mathrm{K}\end{array}$ & $\mathbf{J}$ & $\mathrm{T}$ & $\mathrm{B}$ & B & SB \\
\hline
\end{tabular}

Tahapan yang diawali untuk mencari diagnosa gangguan dalaha dengan mengambil data sampel atau data jenis diagnosapada tabel 4 di atas:

Data uji 1:

Tabel 5 Data Uji 1

\begin{tabular}{|l|c|l|l|l|l|l|c|}
\hline No. & Data & No. & Data & No. & Data & No. & Data \\
\hline $\mathbf{1}$ & KK & $\mathbf{1 1}$ & TT & $\mathbf{2 1}$ & TT & $\mathbf{3 1}$ & BB \\
\hline $\mathbf{2}$ & BB & $\mathbf{1 2}$ & KK & $\mathbf{2 2}$ & TT & $\mathbf{3 2}$ & BB \\
\hline $\mathbf{3}$ & KK & $\mathbf{1 3}$ & KK & $\mathbf{2 3}$ & KK & $\mathbf{3 3}$ & TT \\
\hline $\mathbf{4}$ & TT & $\mathbf{1 4}$ & KK & $\mathbf{2 4}$ & KK & $\mathbf{3 4}$ & TT \\
\hline $\mathbf{5}$ & JJ & $\mathbf{1 5}$ & JJ & $\mathbf{2 5}$ & BB & $\mathbf{3 5}$ & JJ \\
\hline $\mathbf{6}$ & JJ & $\mathbf{1 6}$ & TT & $\mathbf{2 6}$ & BB & $\mathbf{3 6}$ & TT \\
\hline $\mathbf{7}$ & TT & $\mathbf{1 7}$ & TT & $\mathbf{2 7}$ & BB & $\mathbf{3 7}$ & JJ \\
\hline $\mathbf{8}$ & JJ & $\mathbf{1 8}$ & TT & $\mathbf{2 8}$ & KK & $\mathbf{3 8}$ & JJ \\
\hline $\mathbf{9}$ & TT & $\mathbf{1 9}$ & TT & $\mathbf{2 9}$ & TT & $\mathbf{3 9}$ & \\
\hline $\mathbf{1 0}$ & TT & $\mathbf{2 0}$ & TT & $\mathbf{3 0}$ & TT & Diagnosa ?? \\
\hline
\end{tabular}

a. Penyelesaian

\section{Hitung $\mathbf{P}(\mathbf{C i})$}

$P=($ Diagnosa $=" A S D ") 6 / 10=0,6$

$\mathrm{P}=($ Diagnosa="BUKAN") $4 / 10=0,4$

Selanjutnya menghitung jumlah kasus yang sama dengan class yang sama pada tahap ini digabungkan dengan metode Laplacian untuk mengatasi nilai probabilitas nol (0) Dari sekian banyak data di training set, setiap perhitungan yang tidak memiliki kesamaan atau jumlah kemunculannya adalah (0) maka kemunculan yang ada pada setiap class ditambah satu (1) dan nilai masing-masing class sebagai pembagi ditambah dengan total class (2).

Hitung $\mathbf{P}(\mid \mathbf{C i})$
Volume 8, Nomor 2, Tahun 2019

\begin{tabular}{|c|c|c|c|c|c|c|c|c|c|c|}
\hline \multirow{2}{*}{$\begin{array}{l}\text { Gejal } \\
\text { a }\end{array}$} & \multicolumn{10}{|c|}{ Data Ke- } \\
\hline & 1 & 2 & 3 & 4 & 5 & 6 & 7 & 8 & 9 & 10 \\
\hline G35 & $\mathrm{T}$ & $\mathrm{T}$ & $\mathrm{T}$ & $\mathrm{T}$ & $\mathrm{T}$ & $\mathrm{T}$ & $\mathrm{T}$ & $\begin{array}{l}\mathrm{K} \\
\mathrm{K}\end{array}$ & $\begin{array}{l}\mathrm{K} \\
\mathrm{K}\end{array}$ & B \\
\hline G36 & $\mathrm{T}$ & $\mathrm{T}$ & $\mathrm{T}$ & $\mathrm{T}$ & $\mathrm{J}$ & $\mathrm{T}$ & $\mathrm{T}$ & $\begin{array}{l}\mathrm{K} \\
\mathrm{K}\end{array}$ & $\begin{array}{l}\mathrm{K} \\
\mathrm{K}\end{array}$ & $\begin{array}{l}\mathrm{K} \\
\mathrm{K}\end{array}$ \\
\hline G37 & $\mathrm{T}$ & $\mathrm{T}$ & $\mathrm{T}$ & $\mathrm{T}$ & $\mathrm{J}$ & $\mathrm{T}$ & $\mathrm{T}$ & $\begin{array}{l}\mathrm{K} \\
\mathrm{K} \\
\end{array}$ & $\begin{array}{l}\mathrm{K} \\
\mathrm{K} \\
\end{array}$ & $\begin{array}{l}\mathrm{K} \\
\mathrm{K} \\
\end{array}$ \\
\hline G38 & $\mathrm{T}$ & $\mathrm{T}$ & $\mathrm{T}$ & $\mathrm{T}$ & $\mathrm{J}$ & $\mathrm{T}$ & $\mathrm{T}$ & B & $\begin{array}{l}\mathrm{K} \\
\mathrm{K}\end{array}$ & $\begin{array}{l}\mathrm{K} \\
\mathrm{K} \\
\end{array}$ \\
\hline G39 & $\mathrm{T}$ & $\mathrm{J}$ & $\mathrm{T}$ & $\mathrm{T}$ & $\mathrm{J}$ & $\mathrm{T}$ & $\mathrm{T}$ & B & B & $\begin{array}{l}\mathrm{K} \\
\mathrm{K}\end{array}$ \\
\hline $\begin{array}{l}\text { Diag } \\
\text { nosa }\end{array}$ & $\begin{array}{l}\text { A } \\
\text { S } \\
\text { D }\end{array}$ & $\begin{array}{l}\text { A } \\
\text { S } \\
\text { D }\end{array}$ & $\begin{array}{l}\mathbf{A} \\
\mathbf{S} \\
\mathbf{D}\end{array}$ & $\begin{array}{l}\text { A } \\
\text { S } \\
\text { D }\end{array}$ & $\begin{array}{l}\mathbf{B} \\
\mathbf{U} \\
\mathbf{K} \\
\mathbf{A} \\
\mathbf{N}\end{array}$ & $\begin{array}{l}\text { A } \\
\text { S } \\
\text { D }\end{array}$ & $\begin{array}{l}\text { A } \\
\text { S } \\
\text { D }\end{array}$ & $\begin{array}{l}\mathbf{B} \\
\mathbf{U} \\
\mathbf{K} \\
\mathbf{A} \\
\mathbf{N}\end{array}$ & $\begin{array}{l}\mathbf{B} \\
\mathbf{U} \\
\mathbf{K} \\
\mathbf{A} \\
\mathbf{N}\end{array}$ & $\begin{array}{l}\mathbf{B} \\
\mathbf{U} \\
\mathbf{K} \\
\mathbf{A} \\
\mathbf{N}\end{array}$ \\
\hline
\end{tabular}

Tabel 6 Kemunculan Gejala

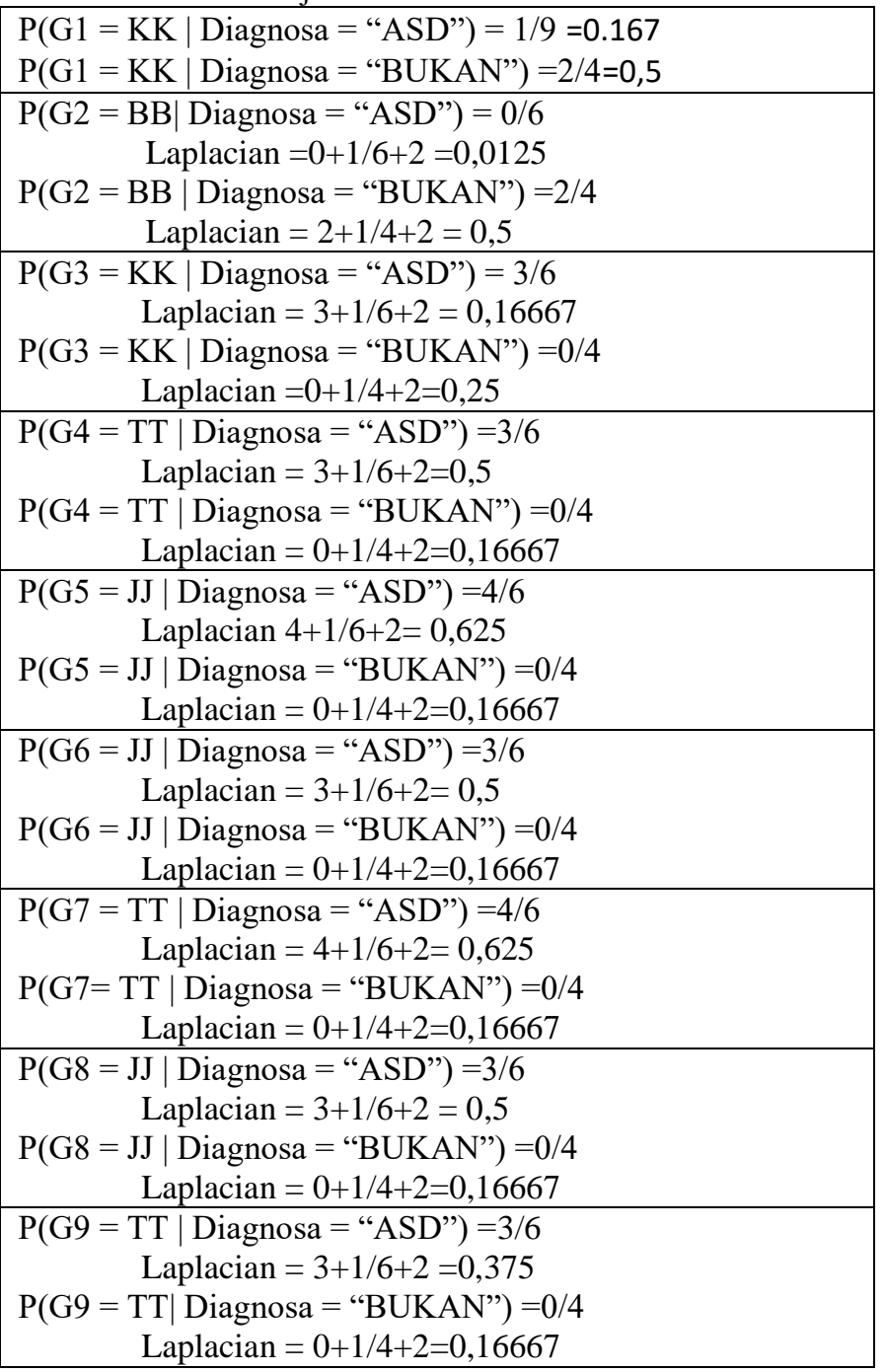


ISSN 2252-9063

Kumpulan Artikel Mahasiswa Pendidikan Teknik Informatika

(KARMAPATI)

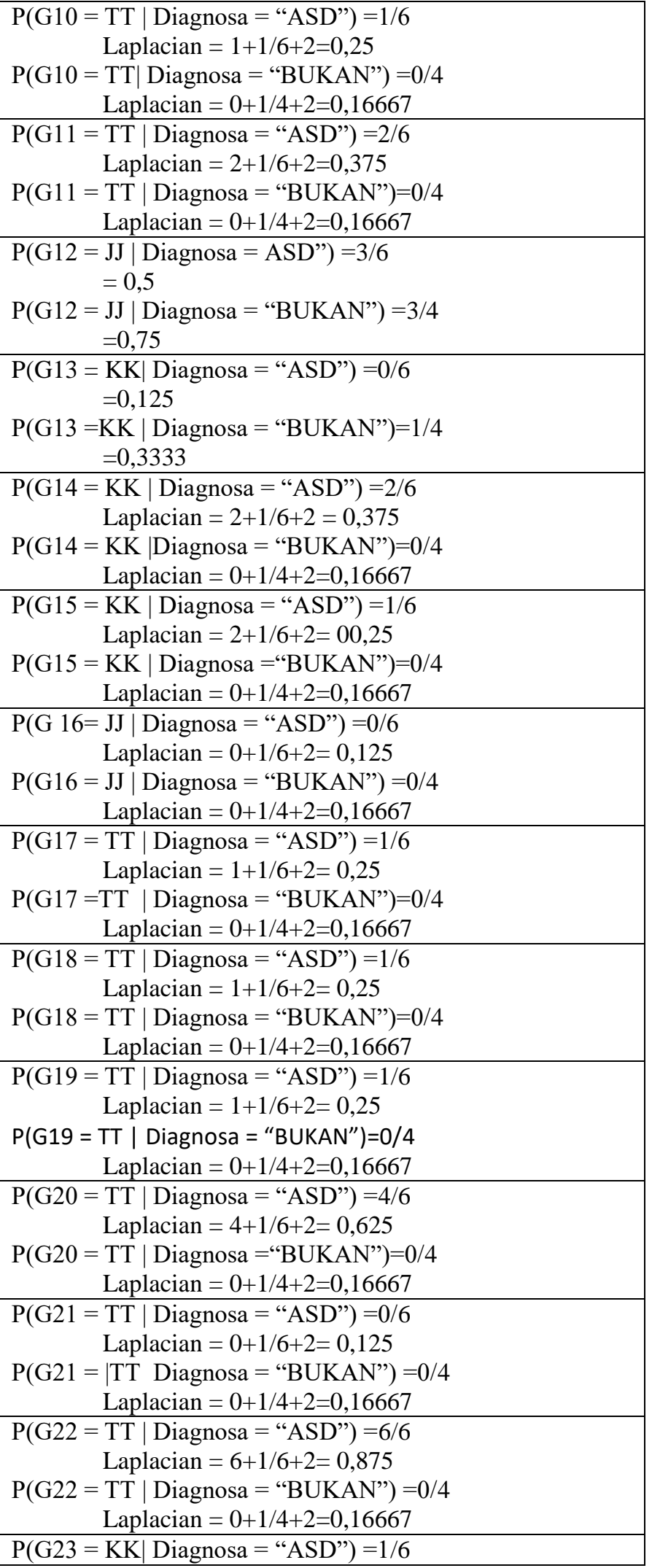
$=0,16667$

$\mathrm{P}(\mathrm{G} 23=\mathrm{KK} \mid$ Diagnosa $=$ "BUKAN" $)=1 / 4$ $=0,25$

$\mathrm{P}(\mathrm{G} 24=\mathrm{KK} \mid$ Diagnosa $=$ "ASD” $)=1 / 6$ $=0,16667$

$\mathrm{P}(\mathrm{G} 24=\mathrm{KK} \mid$ Diagnosa $=$ "BUKAN" $)=3 / 4$ $=0,75$

$\mathrm{P}(\mathrm{G} 25=\mathrm{BB} \mid$ Diagnosa $=$ "ASD" $)=0 / 6$ Laplacian $=0+1 / 6+2=0,125$

$\mathrm{P}(\mathrm{G} 25=\mathrm{BB} \mid$ Diagnosa $=$ "BUKAN" $)=1 / 4$ Laplacian $=1+1 / 4+2=0,3333$

$\mathrm{P}(\mathrm{G} 26=\mathrm{BB} \mid$ Diagnosa $=$ "ASD" $)=0 / 6$ Laplacian $=0+1 / 6+2=0,125$

$\mathrm{P}(\mathrm{G} 26=\mathrm{BB} \mid$ Diagnosa $=$ "BUKAN" $)=1 / 4$ Laplacian $=1+1 / 4+2=0,3333$

$\mathrm{P}(\mathrm{G} 27=\mathrm{BB} \mid$ Diagnosa $=$ "ASD") $=0 / 6$ Laplacian $=0+1 / 6+2=0,125$

$\mathrm{P}(\mathrm{G} 27=\mathrm{BB} \mid$ Diagnosa $=$ "BUKAN" $)=1 / 4$ Laplacian $=1+1 / 4+2=0,3333$

$\mathrm{P}(\mathrm{G} 28=\mathrm{KK} \mid$ Diagnosa $=$ "ASD” $)=0 / 6$ Laplacian $=0+1 / 6+2=0,125$

$\mathrm{P}(\mathrm{G} 28=\mathrm{KK} \mid$ Diagnosa $=$ "BUKAN" $)=4 / 4$ Laplacian $=4+1 / 1+2=0,8333$

$\mathrm{P}(\mathrm{G} 29=\mathrm{TT} \mid$ Diagnosa $=$ "ASD" $)=3 / 6$ Laplacian $=3+1 / 6+2=0,125$

$\mathrm{P}(\mathrm{G} 29=\mathrm{TT} \mid$ Diagnosa $=$ "BUKAN" $)=0 / 4$ Laplacian $=0+1 / 1+2=0,16667$

$\mathrm{P}(\mathrm{G} 30=\mathrm{TT} \mid$ Diagnosa $=$ "ASD" $)=2 / 6$ Laplacian $=2+1 / 6+2=0,375$

$\mathrm{P}(\mathrm{G} 30=\mathrm{TT} \mid$ Diagnosa $=$ "BUKAN" $)=0 / 4$ Laplacian $=0+1 / 4+2=0,16667$

$\mathrm{P}(\mathrm{G} 31=\mathrm{BB} \mid$ Diagnosa $=$ "ASD" $)=0 / 6$ Laplacian $=0+1 / 6+2=0,125$

$\mathrm{P}(\mathrm{G} 31=\mathrm{BB} \mid$ Diagnosa $=$ "BUKAN" $)=3 / 4$ $=$ Laplacian $=3+1 / 4+2=0,6667$

$\mathrm{P}(\mathrm{G} 32=\mathrm{BB} \mid$ Diagnosa $=$ "ASD" $)=0 / 6$ Laplacian $=0+1 / 6+2=0,125$

$\mathrm{P}(\mathrm{G} 32=\mathrm{BB} \mid$ Diagnosa $=$ "BUKAN") $=2 / 4$ Laplacian $=2+1 / 4+2=0,5$

$\mathrm{P}(\mathrm{G} 33=\mathrm{TT} \mid$ Diagnosa $=$ "ASD" $)=5 / 6$ Laplacian $=5+1 / 6+2=0,75$

$\mathrm{P}(\mathrm{G} 33=\mathrm{TT} \mid$ Diagnosa $=$ "BUKAN" $)=0 / 4$ Laplacian $=0+1 / 4+2=0,16667$

$\mathrm{P}(\mathrm{G} 34=\mathrm{TT} \mid$ Diagnosa $=$ "ASD" $)=4 / 6$ Laplacian $=4+1 / 6+2=0,625$

$\mathrm{P}(\mathrm{G} 34=\mathrm{TT} \mid$ Diagnosa $=$ "BUKAN" $)=0 / 4$ Laplacian $=0+1 / 4+2=0,16667$

$\mathrm{P}(\mathrm{G} 35=\mathrm{JJ} \mid$ Diagnosa $=$ "ASD” $)=0 / 6$ Laplacian $=0+1 / 6+2=0,125$

$\mathrm{P}(\mathrm{G} 35=\mathrm{JJ} \mid$ Diagnosa $=$ "BUKAN") $=0 / 4$ Laplacian $=0+1 / 4+2=0,16667$

$\mathrm{P}(\mathrm{G} 36=\mathrm{TT} \mid$ Diagnosa $=$ "ASD" $)=6 / 6$ Laplacian $=6+1 / 6+2=0875$ 


\begin{tabular}{|c|}
\hline $\begin{array}{c}\mathrm{P}(\mathrm{G} 36=\mathrm{TT} \mid \text { Diagnosa }=\text { "BUKAN") }=0 / 4 \\
\text { Laplacian }=0+1 / 4+2=0,16667\end{array}$ \\
\hline $\begin{aligned} \mathrm{P}(\mathrm{G} 37= & \mathrm{JJ} \mid \text { Diagnosa }=\text { "ASD") }=0 / 6 \\
& \text { Laplacian }=3+1 / 6+2=0,125 \\
\mathrm{P}(\mathrm{G} 37= & \mathrm{JJ} \mid \text { Diagnosa }=\text { "BUKAN") }=1 / 4 \\
& \text { Laplacian }=1+1 / 4+2=0,3333\end{aligned}$ \\
\hline $\begin{aligned} \mathrm{P}(\mathrm{G} 38= & \mathrm{JJ} \mid \text { Diagnosa }=\text { "ASD" })=0 / 6 \\
& \text { Laplacian }=0+1 / 6+2=0,125 \\
\mathrm{P}(\mathrm{G} 38= & \mathrm{JJ} \mid \text { Diagnosa }=\text { "BUKAN" })=1 / 4 \\
& \text { Laplacian }=1+1 / 4+2=0,3333\end{aligned}$ \\
\hline $\begin{array}{c}\mathrm{P}(\mathrm{G} 39=\mathrm{TT} \mid \text { Diagnosa }=“ \mathrm{ASD} ")=5 / 6 \\
\text { Laplacian }=5+1 / 6+2=0,75 \\
\mathrm{P}(\mathrm{G} 39 /=\mathrm{TT} \mid \text { Diagnosa }=\text { "BUKAN") }=0 / 4 \\
\text { Laplacian }=1+1 / 4+2=0,3333\end{array}$ \\
\hline
\end{tabular}

Maka :

$\mathbf{P}(\mathbf{X} \mid$ Diagnosa $=$ "ASD" $)=0,16667 \times 0,125 \times 0,16667 \times 0,5$ x $0,625 \times 0,5 \times 0,625 \times 0,5 \times 0,375 \times 0,25 \times 0,375 \times 0,5 \times 0,125$ x $0,375 \times 0,25 \times 0,125 \times 0,25 \times 0,25 \times 0,25 \times 0,625 \times 0,125 \times$ $0,875 \times 0,16667 \times 0,16667 \times 0,125 \times 0,125 \times 0,125 \times 0,125 \times$ $0,5 \times 0,375 \times 0,125 \times 0,125 \times 0,75 \times 0,625 \times 0,125 \times 0,875 \times$ $0,125 \times 0,75=35,566^{-23}$

$\mathbf{P}(\mathbf{X} \mid$ Diagnosa $=$ "BUKAN" $)=0,5 \times 0,5 \times 0,25 \times 0,16667 \times$ 0,16667 x 0,16667 x 0,16667 x 0,16667 x 0,16667 x 0,16667 x $0,16667 \times 0,75 \times 0,3333 \times 0,16667 \times 0,16667 \times 0,16667 \times$ $0,16667 \times 0,166670,16667 \times 0,16667 \times 0,16667 \times 0,16667 \times$ $0,25 \times 0,75 \times 0,3333 \times 0,3333 \times 0,3333 \times 0,8333 \times 0,16667 \times$ $0,16667 \times 0,6667 \times 0,5 \times 0,16667 \times 0,16667 \times 0,16667 \times$ $0,16667 \times 0,3333 \times 0,3333 \times 0,16667=7,06777^{-25}$

Maka :

$\mathbf{P}(\mathrm{X}) \mid$ Diagnosa = "ASD") $\mathbf{P}($ Hasil= "ASD")

$=35,566^{-23} \times 0,6=3,3397^{-23}$

$\mathbf{P}(\mathrm{X}) \mid$ Diagnosa = "BUKAN") $\mathbf{P}($ Hasil= "BUKAN") $=7,06777^{-25} \mathrm{x} 0,4=2,8711^{-25}$

Selanjutnya dalah membandingkan nilai hasil karena nilai ASD lebih bsar dari nilai bukan maka diagnosa gangguannya adalaha ASD.

\section{METODOLOGI PENELITIAN}

\section{A. Metode Penelitian}

Metode penelitian yang digunakan untuk Pengembnagan Sistem Pakar Diagnosa Gangguan Autisme Menggunakan Metode Naive Bayes" adalah menggunakan metode Research and Development model ADDIE. Model ADDIE merupakan singkatan dari Analysis, Design, Development, Implemnetation, and Evaluation. ADDIE adalah model perancangan instruksional yang berupa proses umum yang secara tradisional digunakan oleh para perancang instruksional atau pengembangan pelatihan [10]. dapun gambaran alur dari model ADDIE terdapat pada Gambar 1.
Volume 8, Nomor 2, Tahun 2019

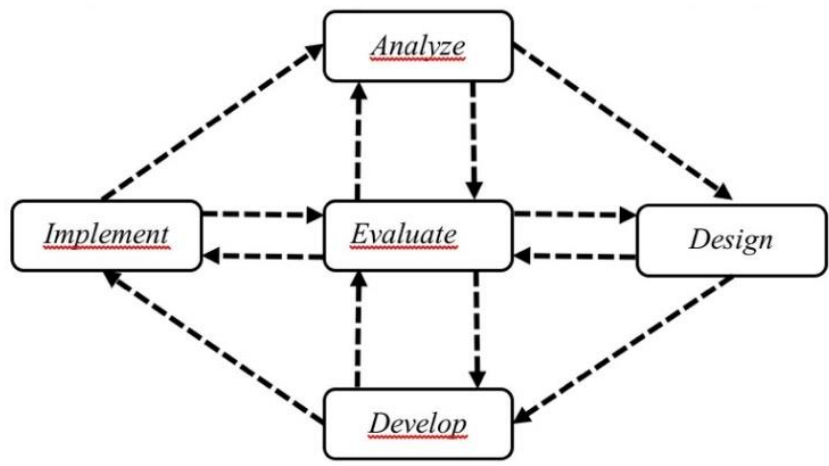

Gambar 1. Ilustrasi model ADDIE

\section{PROSEDUR PENELITIAN}

\section{Analysis}

Pada tahapan ini peneliti melakukan studi pendahuluan berupa pendefinisian masalah instruksional, tujuan instruksional, sasaran sistem serta penggalian informasi terkait sistem yang akan di bangun melalui wawancara kepada pakar dan orang tua serta study literatur menggunakan beberapa buku sebagai pendukung.. Selain itu pencarian informasi terkait teori tentang Metode Naive Bayes yang akan di terapkan untuk membangun sistem. Setelah semua data terkumpul dilanjutkan dengan analisis kebutuhan sistem dan batasan masalah dari sistem yang akan di bangun, sehingga bisa lebih jelas dan bisa di selesaikan sesuai dengan waktu yang ada.

\section{Design}

Pada tahap desain ini dilakukan setelah tahap analisis dan pendefinisian kebutuhan sistem sudah terpenuhi. Pada tahap ini dilakukan tahap perancangan sistem yang kemudian nantinya akan menjadi acuan untuk tahap implementasi. Pada tahapan ini akan dipaparkan mengenai batasan fungsionalitas dan nonfungsionalitas dari perangkat lunak, desain antarmuka, basisdata, perancangan arsitektur perangkat lunak.

\section{Implementation}

Pada tahap ini semua tahap diimplementasikan berdasarkan tahapan-tahapan yang sudah dilakukan sebelumnya. Agar dapat mengetahui semua modul-modul yang dibuat berfungsi sesuai kebutuhan. Semua modul yang sudah dibuat akan digabungkan menjadi suatu sistem utuh yang selanjutnya akan dilakukan pengujian sistem secara white box atau black box, uji akurasi dan uji respons pengguna terhadap sistem.

\section{Evaluation}

Tahap evaluasi atau pengujian hasil dari implementasi perangkat lunak akan diujikan, untuk mengetahui apakah seluruh komponen aplikasi sudah berjalan dengan baik sesuai dengan fungsionalitasnya termasuk mampu untuk 
meminimalisir kesalahan (error) pada sistem. Selanjutnya akan dilakukan pengujian mengenai apakah aplikasi dapat digunakan oleh pengguna awam dengan menggunakan pengujian Software Usability Scale (SUS).

\section{HASIL DAN PEMBAHASAN}

\section{A. HASIL}

Berdasarkan hasil penelitian yang telah dipaparkan sebelumnya, beberapa tahap penelitian yang dilakukan dalam penelitian dalam penelitian ini yaitu, Analyze (analisis), Design (desain), Development (pengembangan), Implementation (implementasi), dan Evaluation (evaluasi). Hasil dari setiap tahapan penelitian pada Sistem Pakar Diagnosa Gangguan Autisme dengan masing-masing tahapan Analysis, Design, Development, Implementation, Evaluation (ADDIE) adalah sebagai berikut

a) Analysis (analisis)

Tahap analisis merupakan tahap awal dari proses penelitian ini terhadap aplikasi yang dikembangkan. Pada proses analisis mencangkup analisis masalah beserta usulan solusi dan analisis kebutuhan sistem yang meliputi kebutuhan fungsional maupun non Berdasarkan dari tahap analisis kebutuhan sistem yang sudah dilakukan, maka didapatkan kebutuhan fungsional dan non fungsional yangfungsional, kebuthan perangkat keras, dan kebutuhan perangkat lunak. diperlukan dalam membangun sistem ini antara lain:

1. Kebutuhan Fungsional

a. User dapat mengelola data akun.

b. User dapat menampilkan data gejala

c. User dapat mengisi data gejala yang sudah disediakan oleh sistem.

d. User dapat melihat hasil diagnosa gangguan

e. User dapat memilih training penanganan untuk anak Autisme.

f. User dapat melihat histori jawaban yang sudah dipilih

2. Kebutuhan non fungsional

a. Sistem pakar diagnosa gangguan autisme dilengkapi dengan proses login.

b. Sistem ini dapat digunakan pada PC/komputer dan laptop yang sudah memiliki browser.

c. Sistem memiliki rancangan antarmuka yang user friendly.

d. Probability, basis data yang tersimpan secara online memudahkan untuk mengaksesnya.

Setelah itu, penulis melakukan analisa data untuk menentukan metode yang sesuai dan penyesuaian tentang jawaban pertanyaan. Saat melakukan percobaan pertanyaan untuk analisa sistem ditemukan masalah dimana orang tua merasa kesulitan untuk memberikan nilai kemampuan anak, dimana kecendrungan orang tua menyebutkan tentang intensitas kelaakuan dari seorang anak. Maka dari itu berdasarkan permasalahan yang ada model jawaban pengguna di ubah dari penskoran ke skala linkert dimana jawaban pertanyaan menggunakan 5 pilihan yaitu Tidak, Jarang, Kadang-kadang, Baik dan Sangat Baik. Selanjutnya dilakukan pemodelan sistem dengan menggunakan UML (Unified Modelling Language) yang meliputi, Use Case Diagram dan Activty Diagram

\section{Use Case Diagram}

Dari hasil Analisa terhadap kebutuhan Sistem Pakar Diagnosa Gangguan Autisme maka diperoleh rancangan use case yang dapat dilihat pada Gambar 2 .

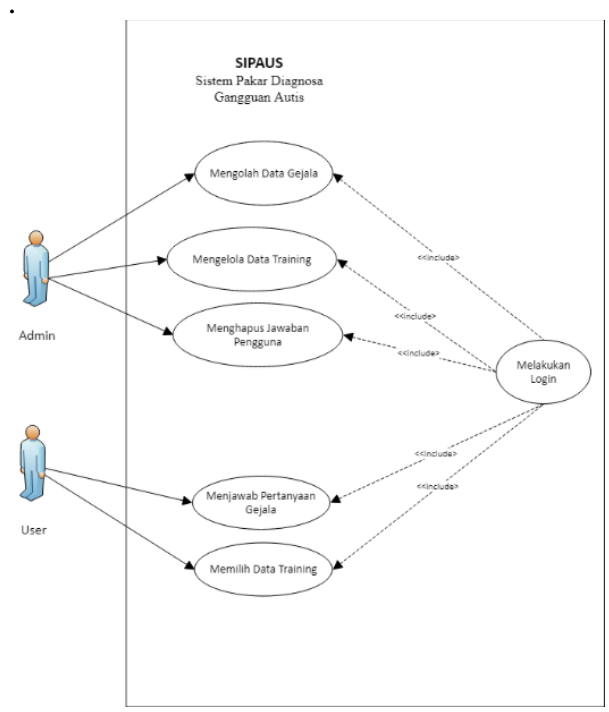

Gambar 2. Use Case Diagram

2. Activity Diagram

Activity Diagram ini menggambarkan berbagai alur aktivitas dalam sistem yang sedang dirancang, bagaimana masing-masing alur berawal, decision yang mungkin terjadi, dan bagaimana alur berakhir.Berikut ini adalah gambaran activity diagram jawab pertanyaan yang dapat dilihat pada Gambar 3. 


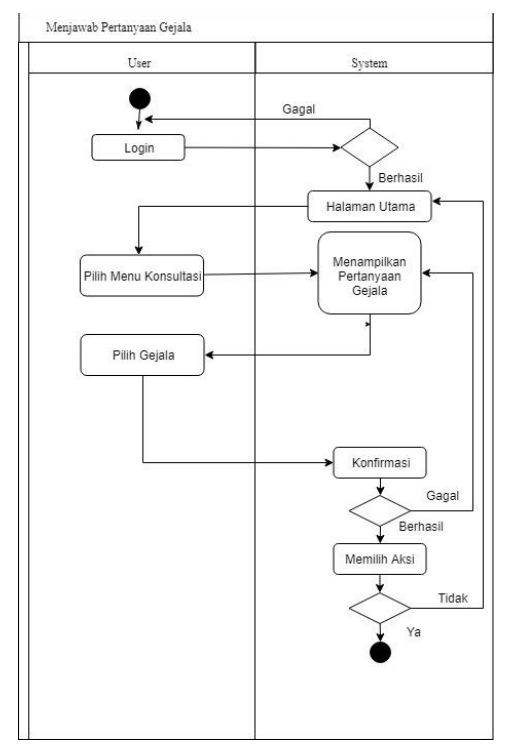

Gambar 3. Activity Diagram Jawab Pertanyaan

b) Design (Desain)

Pada tahap ini mulai dilakukan perancangan terhadap database dan database yang akan digunakan pada sistem, adapun gambaran dari proses desain tersebut adalah sebagai berikut:

a. Rancangan Database Sistem Pakar Gangguan Autisme.

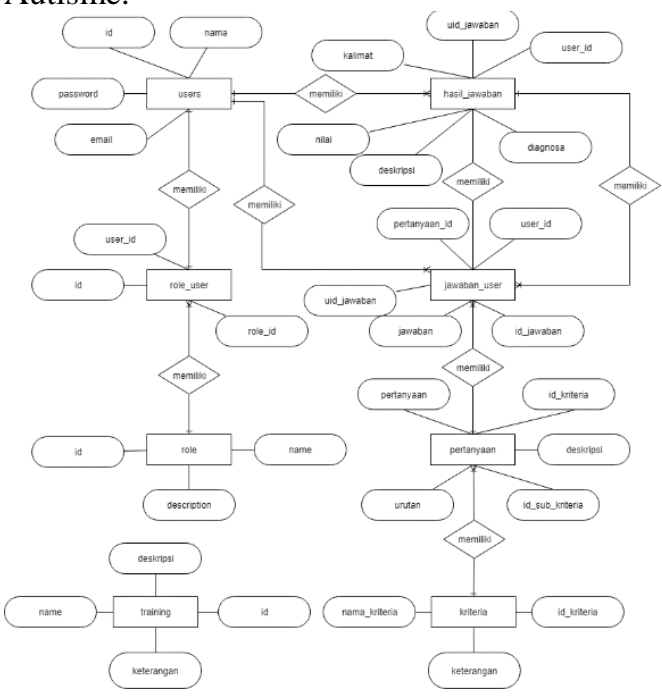

Gambar 4 Rancangan Database

b. Rancangan Tampilan Sistem Pakar Gangguan Autisme.

1. Rancangan Halaman Awal Sistem Pakar Halaman ini merupakan tampilan awal saat pengguna mengakses sistem.
Volume 8, Nomor 2, Tahun 2019

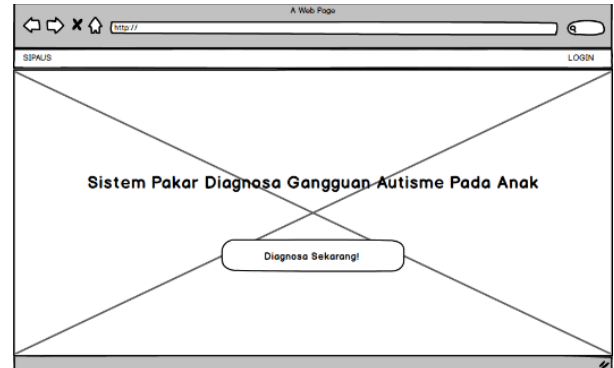

Gambar 5. Rancangan Halaman Awal

2. Rancangan Halaman Jawab Pertanyaan Gejala

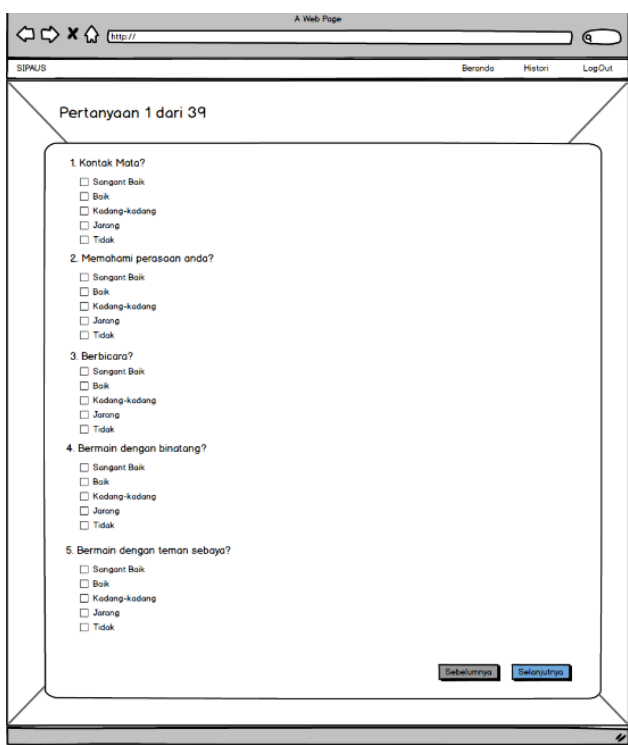

Gambar 6 Rancanagn Halaman Jawab Pertanyaan Gejala

3. Rancangan Halaman Hasil Diagnosa

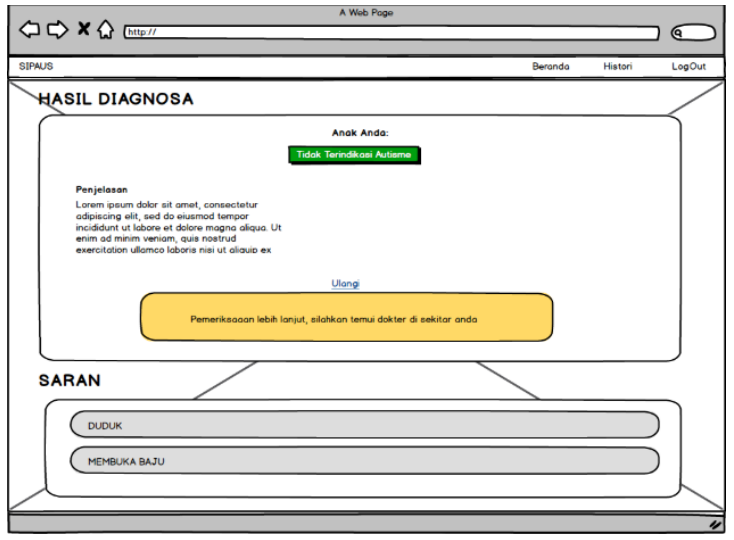

Gambar 7. Rancanagn Halaman Hasil Diagnosa 
ISSN 2252-9063

Kumpulan Artikel Mahasiswa Pendidikan Teknik Informatika

(KARMAPATI)

c) Development (Implementasi)

Lingkungan perangkat lunak memaparkan tentang spesifikasi perangkat keras dan perangkat lunak yang diperlukan untuk membuat sistem.Pada tahap development dilakukan pengembangan terhadap desain yang sudah dibuat sebelumnya yang akan diterjemahkan kedalam kode Bahasa Pemrograman. Dalam proses pembuatan akan dipecah menjadi modul-modul yang lebih kecil,yang nantinya akan digabungkan pada tahap berikutnya menjadi sistem utuh. Dalam pembuatan kode Bahasa pemrograman tersebut, tentunya peneliti membutuhkan beberapa perangkat lunak yang akan digunakan dalam implementasi. Adapun spesifikasi tersebut dapat dikategorikan ke dalam spesifikasi perangkat keras dan perangkat lunak. Berikut merupakan detail dari spesifikasi yang digunakan antara lain:

a. Spesifikasi Perangkat Lunak

1) XAMPP sebagai Web Server dan penyedia MySQL.

2) Laravel sebagai PHP Framework

3) Visual Studio Code sebagai kode editor pengembangan perangkat lunak.

b. Spesifikasi Perangkat Keras

1) Laptop Asus A450L

2) Processor Intel Core i5-42000U

3) RAM 8GB

4) Layar 14 inch dengan resolusi 1366 x 768 pixel

Selanjutnya untuk Antarmuka tampilan Sistem dapat dilihat pada gambar dibawah ini.

1. Antarmuka Halaman Login

Implementasi tampilan ini merupakan tampilan Login sebelum pengguna memasuki sistem.

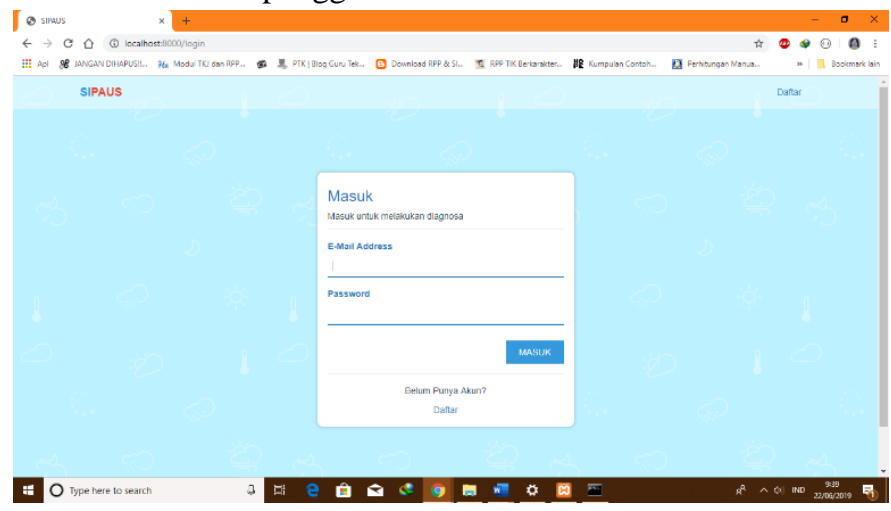

Gambar 8. Antarmuka Halaman Login
2. Antarmuka Jawab Pertanyaan Gejala

Tampilan ini berfungsi sebagai antarmuka untuk menampilkan pertanyaan gejala yang akan di isi oleh pengguna sistem.

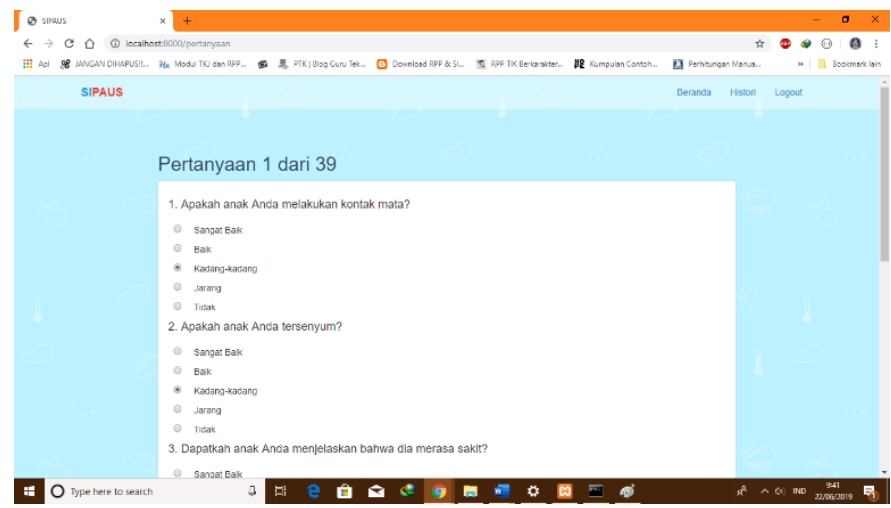

Gambar 9. Antarmuka Jawab Pertanyaan Gejala

\section{d) Evaluation (Evaluasi)}

Pada saat setelah dilakukannya implementasi perangkat lunak, dilakukan tahapan pengujian. Tahap ini merupakan tahap di mana rancangan aplikasi yang telah dibuat di implementasikan untuk selanjutnya dilakukan pengujian untuk mengetahui apakah semua komponen pada aplikasi sudah berjalan sesuai dengan fungsinya. Dalam penelitian ini duganakan 5 jenis pengujiana sebagai berikut:

\section{Pengujian Black Box}

Menurut Rosa dan Shalahudin 2014 "Black Box Testing adalah pengujian perangkat lunak dari segi spesifikasi fungsional tanpa menguji desain atau kode program". Pengujian dimaksudkan untuk mengetahui fungsi-fungsi masukan dan keluaran dari perangkat lunak sesuai dengan spesifikasi yang dibutuhkan dan pengujian dengan black box testing memungkinkan pengembang software untuk membuat himpunan kondisi input yang akan melatih seluruh syarat-syarat fungsional suatu program. Pengujian dilakukan oleh 3 responden yaitu 2 orang user dan 1 orang admin. Dimana dalam hasil pengujiannya didapatkan hasil sistem telah sesuai. 
ISSN 2252-9063

Kumpulan Artikel Mahasiswa Pendidikan Teknik Informatika

(KARMAPATI)

Volume 8, Nomor 2, Tahun 2019

2. Pengujian White Box

Menurut (Rosa \& Shalahuddin, 2013), whitebox testing bertujuan untuk menguji perangkat lunak dari segi desain dan kode program, apakah mampu menghasilkan fungsi-fungsi, masukan, dan keluaran yang sesuai dengan spesifikasi kebutuhan. Whitebox Testing dilakukan dengan memeriksa logic dari kode program. Pengujian dilakukan dengan mencari jalur atau node dari perhitungan Naive Bayes yang telah di buat pada modil perhitungan gejala.

3. Pengujian Kesesuaian

Pengujian kesesuaian sistem bertujuan untuk mengetahui kesesuaian hasil yang diperoleh sistem terhadap kasus tertentu dengan pembanding berupa hasil manual sehingga sistem dapat menghasilkan kesimpulan yang akurat. Pengujian kesesuain dilakukan oleh 3 orang responden dimana dari 3 inputan data yang dimasukan ke dalam sistem memiliki hasil yang sama dengan perhitungan data manual yang ada. Maka nilai kesesuainnya $100 \%$

4. Pengujian Akurasi

Pengujuan akurasi sistem bertujuan untuk mengetahui tingkat keakuratan dari kesimpulan sistem dengan kesimpulan yang diberikan oleh pakar saat user melakukan konsultasi.Pengujian ini dilakukan. Pengujian akurasi ini dilakukan oleh 2 orang guru anak disabilitas mental dan seorang pakar, Dimana hasil yang ada pada sistem akan dibandingkan langsung dengan hasil diagnosa yang dimiliki oleh pakar. Dari 15 data uji akurasi yang ada didapatkan hasil sebagai berikut:

Tabel 7 Data Uji Akurasi

\begin{tabular}{|c|c|c|c|}
\hline No & Diagnosa Pakar & Diagnosa Sistem & $\begin{array}{c}\text { Nila } \\
\text { Keakuratan }\end{array}$ \\
\hline 1 & $\begin{array}{c}\text { Terindikasi } \\
\text { Autisme }\end{array}$ & $\begin{array}{c}\text { Terindikasi } \\
\text { Autisme }\end{array}$ & 1 \\
\hline 2 & $\begin{array}{c}\text { Terindikasi } \\
\text { Autisme }\end{array}$ & $\begin{array}{c}\text { Terindikasi } \\
\text { Autisme }\end{array}$ & 1 \\
\hline 4 & $\begin{array}{c}\text { Terindikasi } \\
\text { Autisme }\end{array}$ & $\begin{array}{c}\text { Terindikasi } \\
\text { Autisme }\end{array}$ & 1 \\
\hline 5 & $\begin{array}{c}\text { Tidak Terindikasi } \\
\text { Autisme }\end{array}$ & $\begin{array}{c}\text { Tidak Terindikasi } \\
\text { Autisme }\end{array}$ & 1 \\
\hline 6 & $\begin{array}{c}\text { Tidak Terindikasi } \\
\text { Autisme }\end{array}$ & $\begin{array}{c}\text { Tidak Terindikasi } \\
\text { Autisme }\end{array}$ & $\begin{array}{c}\text { Tidak Terindikasi } \\
\text { Autisme }\end{array}$ \\
\hline 7 & $\begin{array}{c}\text { Tidak Terindikasi } \\
\text { Autisme }\end{array}$ & $\begin{array}{c}\text { Tidak Terindikasi } \\
\text { Autisme }\end{array}$ & 1 \\
\hline
\end{tabular}

\begin{tabular}{|c|c|c|c|}
\hline No & Diagnosa Pakar & Diagnosa Sistem & $\begin{array}{c}\text { Nila } \\
\text { Keakuratan }\end{array}$ \\
\hline 8 & $\begin{array}{l}\text { Terindikasi } \\
\text { Autisme }\end{array}$ & $\begin{array}{l}\text { Terindikasi } \\
\text { Autisme }\end{array}$ & 1 \\
\hline 9 & $\begin{array}{c}\text { Tidak Terindikasi } \\
\text { Autisme }\end{array}$ & $\begin{array}{c}\text { Tidak Terindikasi } \\
\text { Autisme }\end{array}$ & 1 \\
\hline 10 & $\begin{array}{l}\text { Terindikasi } \\
\text { Autisme }\end{array}$ & $\begin{array}{l}\text { Terindikasi } \\
\text { Autisme }\end{array}$ & 1 \\
\hline 11 & $\begin{array}{l}\text { Terindikasi } \\
\text { Autisme }\end{array}$ & $\begin{array}{l}\text { Terindikasi } \\
\text { Autisme }\end{array}$ & 1 \\
\hline 12 & $\begin{array}{c}\text { Tidak Terindikasi } \\
\text { Autisme }\end{array}$ & $\begin{array}{c}\text { Tidak Terindikasi } \\
\text { Autisme }\end{array}$ & 1 \\
\hline 13 & $\begin{array}{c}\text { Tidak Terindikasi } \\
\text { Autisme }\end{array}$ & $\begin{array}{c}\text { Tidak Terindikasi } \\
\text { Autisme }\end{array}$ & 1 \\
\hline 14 & $\begin{array}{l}\text { Terindikasi } \\
\text { Autisme }\end{array}$ & $\begin{array}{l}\text { Terindikasi } \\
\text { Autisme }\end{array}$ & 1 \\
\hline 15 & $\begin{array}{l}\text { Terindikasi } \\
\text { Autisme }\end{array}$ & $\begin{array}{l}\text { Terindikasi } \\
\text { Autisme }\end{array}$ & 1 \\
\hline \multicolumn{3}{|c|}{ Jumlah Nilai Keakuratan } & 15 \\
\hline
\end{tabular}

Berdasarkan hasil yang diperoleh tingkat akurasi sistem sebagai berikut.

Tingkat Akurasi $=\frac{15}{15} \times 100 \%=100$

\section{Pengujian Software Usability Scale (SUS)}

Pada pengujian ini digunakan 20 responden yang mengisi 10 pertanyaan. Dari pengujian yang dilakukan di dapatkan hasil skor sebesar 75,7 dari 100 namun pada saat dilakukan pengujian terhadap guru dengan anak disabiltas dan dan masyarakat umum banyak responden yang mengatakan perlu belajar lebih jauh sebelum menggunakan sistem ini.

\section{SIMPULAN}

Berdasarkan hasil penelitian dan pembahasan Pengembanagan Sistem Pakar Diagnosa Gangguan Autisme Menggunakan Metode Naive Bayes, maka penulis dapat menarik kesimpulan sebagai berikut.

1. Perancangan Pengembanagan Sistem Pakar Diagnosa Gangguan Autisme Menggunakan Metode Naive Bayes telah berhasil dikembangkan menggunakan metode penelitian ADDIE

2. Pengembanagan Sistem Pakar Diagnosa Gangguan Autisme Menggunakan Metode Naive Bayes sudah melewati pengujian black box dan white box dengan baik. 
3. Berdasrakan uji akurasi dan kesesuaian yang dilakukan pada Pengembanagan Sistem Pakar Diagnosa Gangguan Autisme Menggunakan Metode Naive Bayes didapatkan hasil presentase sebesar $100 \%$.

4. Berdasarkan analisis terhadap 20 responden yang telah mencoba Sistem Pakar Diagnosa Gangguan Autisme Menggunakan Metode Naive Bayes, didapatkan hasil skor pengujian dengan metode uji SUS sebesar 75,7 dari 100 dimana sistem dapat diterima.

5. Untuk pengembangan lebih lanjut perlu dilakukannya penambahan kriteria gejala, dan jenis diagnosa.

6. Data nilai terlalu banyak memiliki pangkat minus sehingga pada penelitian selanjutnya dapat dilakukan normalisasi.

7. Terdapat kekurangan pada metode Naive Bayes dimana jika hasil nilai ada yang bernilai nol maka akan mempenggaruhi hasil akhir, untuk itu pada penelitian selanjutnya di harapkan dapat menggunakan metode smoothing data.

\section{REFERENSI}

[1] YPAC. (2013). Buku Penanganan dan Pendidikan Autis di YPAC. Dalam Y. P. Cacat

[2] Rahayu, S. M. (2014). Deteksi dan Intervensi Dini Pada anak Autis. Jurnal Pendidikan Anak, 421.

[3] Children, T. (2015, 9 6). Klinik Autis Online. Diambil kembali dari Klinik Autis Online: https://klinikautis.com/2015/09/06/jumlah-penderitaautis-di-indonesia/

[4] Bararah, V. F. (2010, 4 17). Detik Health. Diambil kembali dari Detik Health: http://health.detik.com/read/2010/04/17/142018/1340 191/763/dilema-anak-autis

[5] DR. Dr. Handojo, M. (2003). Autisma. Jakatra: PT. BHUANA ILMU POPULER.

[6] Mann, D. (2012, Mei 24). WebMD. Diambil kembali dari WebMD:

https://www.webmd.com/brain/autism/news/2012052 3/most-children-with-autism-diagnosed-at-5-orolder\#1
[7] Association, A. P. (2013). Diagnostic and Statistical Manual of Mental DIsorder. Whasington DC: American Psychiatric Association.

[8] Saleh, A. (2015). Implementasi Metode Klasifikasi Naïve Bayes Dalam Memprediksi Besarnya Penggunaan Listrik Rumah Tangga. Citec Journal, Vol. 2, No. 3, Mei 2015, 209-212.

[9] Dr. Widodo Budiharto. S.Si., M. \&. (2014). Artificial Intellegence Konsep dan Penerapannya. Jakarta: ANDI.

[10] Tanjung, M. R., \& Parsika, T. F. (2014). PENGEMBANGAN APLIKASI MULTIMEDIA PENGENALAN PEMBELAJARAN DENGAN PENDEKATAN ADDIE. Seminar Internasional Informatika, 128-133. 